\title{
Japanese Persimmon Cultural Practices in Florida ${ }^{1}$
}

\author{
Ali Sarkhosh, Dustin M. Huff, and Peter C. Andersen²
}

\section{Production Areas and Suitability}

Persimmons are considered a relatively sustainable crop in Florida, rated as a 6 out of 10 on an assessment of agricultural sustainability, with a moderate commercial potential and high direct-to-consumer potential. Consumer demand would mostly be for the nonastringent varieties. Persimmons are more suitable for central and north Florida because quality and yields may be lower in the southern part of the state. Persimmons have a low chilling requirement, with success in areas that receive only 100-200 hours below $45^{\circ} \mathrm{F}\left(7^{\circ} \mathrm{C}\right)$, and data shows that bud dormancy may be best released at temperatures just above the normal chilling range of $32^{\circ} \mathrm{F}-45^{\circ} \mathrm{F}\left(0^{\circ} \mathrm{C}-7^{\circ} \mathrm{C}\right)$.

From the 2017 census of agriculture county-level data, it is clear there are two main persimmon production regions in Florida. One region is in the adjoining counties of Alachua, Levy, Marion, and Lake, which account for nearly 50 percent of the total crop acreage for the state (132 of 266 acres). Another region is in the Panhandle, in the adjoining counties of Okaloosa, Walton, and Washington, which total about 18 percent of the production acreage. There are a few other counties scattered around with more than 5 acres: Brevard (16 acres), Hernando (8 acres), and Jefferson (8 acres).
Trees grow and fruit best in central and northern Florida and can produce high yields of good-quality fruit. In south Florida, fruit quality is better with astringent types than with nonastringent types. Japanese persimmons are not listed on either the USDA Florida State Noxious Weeds List or the Florida Exotic Pest Plant Council's List of Invasive Plant Species. For information about cultivars that can be grown in Florida, visit the EDIS publication Japanese Persimmon Cultivars in Florida, available at https://edis.ifas. ufl.edu/mg242.

\section{Propagation Rootstock Selection}

Japanese persimmons in Florida have nearly exclusively been grafted onto Diospyros virginiana, the native persimmon of the United States. D. virginiana is widely used in the southern states due to its adaptability to different soil types. It provides a tolerance of wet soils, is cold hardy, can withstand drought conditions, and is compatible with most scion cultivars. It tends to produce more suckers compared with other common rootstocks used in California, such as D. lotus and D. kaki, and can also lack uniformity and vigor. Some research completed in Florida in the 1960s comparing $D$. kaki and D. virginiana found little difference between the rootstocks regarding yield but did confirm the native

1. This document is HS1389, one of a series of the Horticultural Sciences Department, UF/IFAS Extension. Original publication date October 2020. Visit the EDIS website at https://edis.ifas.ufl.edu for the currently supported version of this publication.

2. Ali Sarkhosh, assistant professor \& Extension specialist; Dustin Huff, biological scientist, Horticultural Sciences Department; and Peter C. Andersen, professor emeritus, Horticultural Sciences Department, UF/IFAS North Florida Research and Education Center, Quincy, FL; UF/IFAS Extension, Gainesville, FL 32611.

The use of trade names in this publication is solely for the purpose of providing specific information. It is not a guarantee or warranty of the products named, and does not signify that they are approved to the exclusion of others of suitable composition. Use pesticides safely. Read and follow directions on the manufacturer's label.

The Institute of Food and Agricultural Sciences (IFAS) is an Equal Opportunity Institution authorized to provide research, educational information and other services

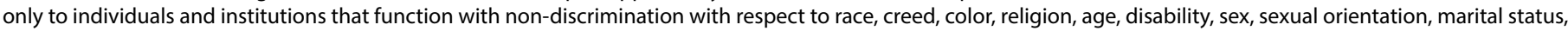

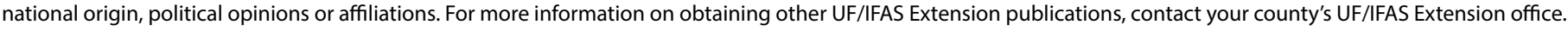
U.S. Department of Agriculture, UF/IFAS Extension Service, University of Florida, IFAS, Florida A \& M University Cooperative Extension Program, and Boards of County Commissioners Cooperating. Nick T. Place, dean for UF/IFAS Extension. 
persimmon stock promoted more suckering. D. lotus has shown some incompatibility with the main nonastringent varieties, including 'Fuyu', 'Jiro', and 'Izu', and may cause higher fruit drop in the astringent 'Hachiya'. Recent promising research from Japan on dwarfing rootstock selections, particularly of SH11, MKR1, and FDR-1, found high yield efficiency and the potential to reduce the labor requirement per tree. Fruit drop has also been shown to be inhibited in some cases by these dwarfing stocks. Future trials in Florida using different scion-rootstock combinations would aid in finding potential benefits that other rootstocks may provide.

\section{Why Persimmons Are Grafted}

Rootstocks in general have their benefits and drawbacks, and their suitability for certain soil conditions and climates can vary, so they should be chosen accordingly. Persimmons are grafted because the success rate of propagation by cuttings can be quite low, particularly hardwood shoot cuttings. Interesting research looking at micropropagated persimmon trees (own-rooted) versus grafted trees found that softwood shoot cuttings from the micropropagated trees had a notably higher average rooting percentage, 22\% vs. $9 \%$, when 3000 ppm IBA (Indole-3-butyric acid) was used for both samples. The highest successful rooting rate was found in softwood root sucker cuttings of micropropagated trees that were produced when the aboveground part of the tree was cut off. It was also noted that shorter cutting lengths of root suckers ( $3-4 \mathrm{~cm} ; 1.2-1.6$ in) displayed a higher rooting rate compared with longer lengths $(25 \mathrm{~cm}$; 10 in), $70 \%$ vs. $30 \%$, respectively. Micropropagation has been known to improve cutting rooting rates due to its rejuvenation effect. It is also thought that the root suckers had better rooting rates compared to the shoots due to the root suckers being more physiologically juvenile. However, because own-rooted trees may be more vigorous than their grafted counterparts, commercial propagation by cuttings may be limited to increasing rootstock, and particularly for dwarfing rootstocks if smaller trees are desired in an orchard. Trees grafted directly onto micropropagated stocks may display negative traits, such as delayed fruiting. Thus, additional research on rootstock performance is warranted.

\section{Propagation of Seedling Rootstocks}

Fruit from local D. virginiana may be harvested, if available, when mature in the fall, and seeds can be removed and rinsed in water to remove the flesh. Seeds may be planted directly after that in potting mix if warm conditions can be provided and maintained, or the moist seeds can be treated with a fungicide and then stored in a plastic bag in a refrigerator between $35^{\circ} \mathrm{F}-45^{\circ} \mathrm{F}$ until planting. It is important that the seeds stay a little moist to maintain viability. Seeds and seedlings of $D$. virginiana may also be found through local nurseries and online sources.

Seeds may be sprouted by first placing them in moist germination paper or newspaper before planting them in potting mix, or they can be germinated in seed beds in a greenhouse in January or February. The younger seedlings can develop sunburnt leaves, so some shading early on is recommended. The seedlings are then grown out for the rest of the year and will be ready for grafting the following winter.

Scion budwood for spring grafting or budding should be collected when dormant, before bud swell, which is generally before mid-March in north Florida. Scion material can be stored in polyethylene bags at $40^{\circ} \mathrm{F}\left(4.4^{\circ} \mathrm{C}\right)$ for several weeks, or up to several months at $32^{\circ} \mathrm{F}\left(0^{\circ} \mathrm{C}\right)$, but should be checked regularly to ensure the cuttings are moist enough to prevent dehydration.

\section{Grafting Methods}

The two common methods of joining the scion and rootstock of persimmons are whip grafting and chip budding. Whip grafting can best be performed during the dormant season. Scion material with two buds provides good results, and the graft union is wrapped with tape or rubber bands. The graft can be covered in a plastic bag to keep humidity high during callusing, and waxing the cut end of the scion may also increase success.

Chip budding (Figure 1) is perhaps the easiest method of propagation. When budding, the chip can be inserted in the rootstock from 1 to 6 inches above the soil line. The ideal time for spring chip budding of persimmon is when the rootstock begins growth, continuing for one month or so after leafing out. Fall chip budding can also be done if it is performed more than six weeks before the first frost to allow time to complete the callousing process. In the case of fall budding, the bud is forced in spring the following year. One key when forcing is to gradually cut the rootstock back to the point of the graft union, and not all the way until the bud has begun growing. It is important to cover the chip and bud with grafting tape to avoid it drying out. Staking newly growing shoots will help prevent them from being broken by the wind.

Other methods of propagating persimmons are used to a lesser extent or are less successful. T-budding can be done, but results may vary. Top grafting (or cleft grafting) (Figure 2) can be a way to change the cultivar being grown in an 
orchard but is typically performed on much older trees. If rootstocks are available, but scion bud wood happens to be limited, one temporary strategy would be to establish the rootstock in the field, and to bud or graft the scion in situ when material is available.

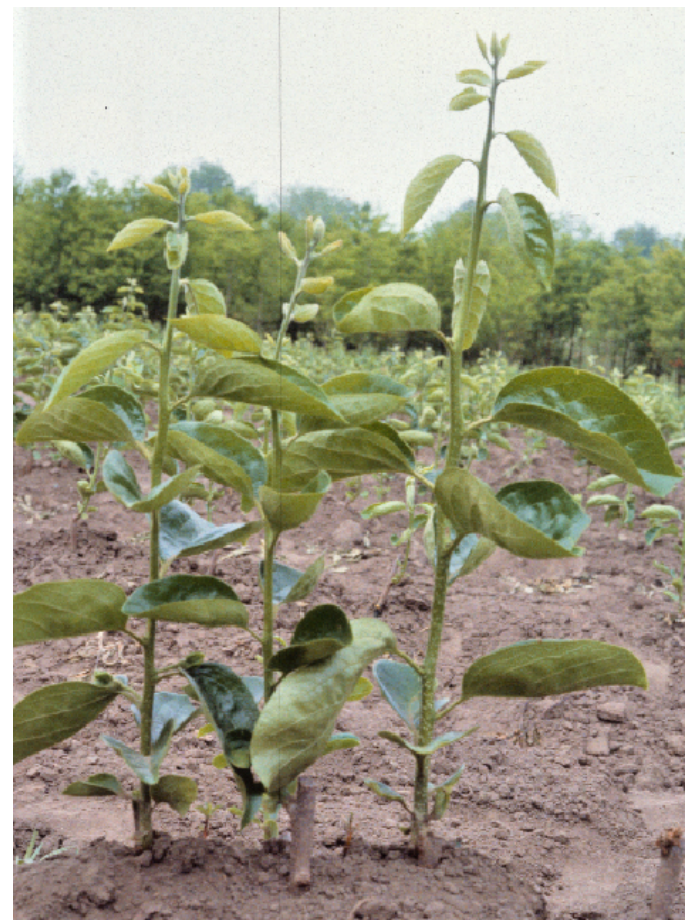

Figure 1. Chip-budded trees.

Credits: UF/IFAS

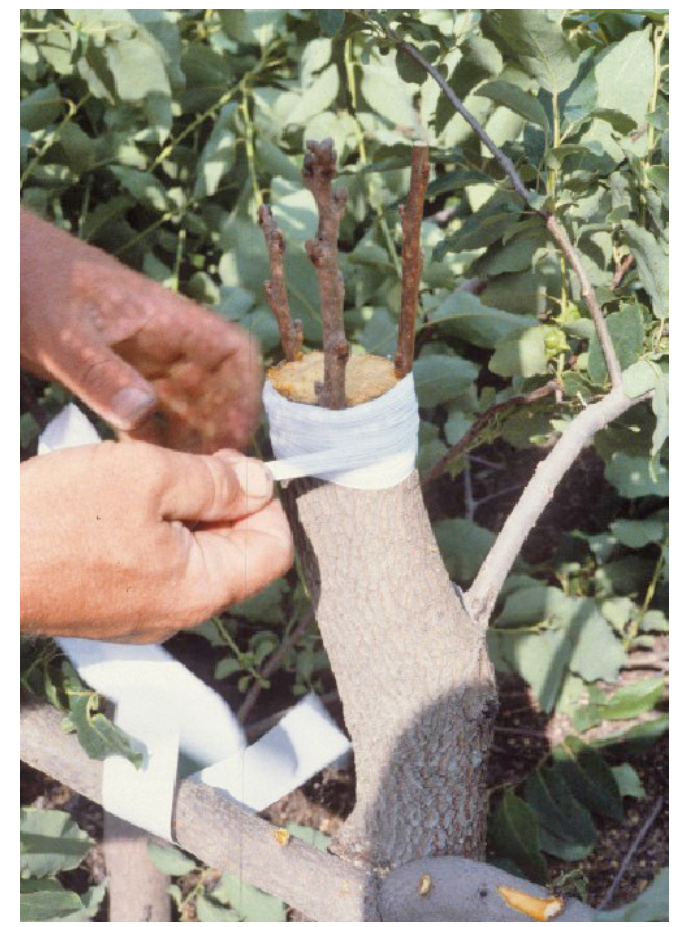

Figure 2. Top-grafting scions.

Credits: UF/IFAS

\section{Field Establishment}

\section{Site Selection}

The best sites for planting persimmon trees are upland sandy loam soils. Avoid low pockets to escape late-spring freeze damage after trees have begun growing. Persimmons perform best in soil $\mathrm{pH}$ of 6 to 7 , and they are sensitive to salinity. The wood of persimmon is considered to be strong, although young shoots and branches that are weighed down with fruit can be sensitive to wind damage. In open locations, it may be necessary to establish windbreaks to lessen this problem.

\section{Spacing}

The most common training system used is the modified central leader, which in most areas, with current rootstocks, can be planted with $15 \mathrm{ft}(4.5 \mathrm{~m})$ between trees and $20 \mathrm{ft}(6$ $\mathrm{m}$ ) between rows, allowing for 145 trees per acre. In soils that have higher or lower natural fertility, spacing can be adapted as needed to take this into account.

\section{Initial Planting}

Bare-root trees should be planted from December through February. This is done by digging a hole larger than the root system and, while keeping the graft union at or above the soil line, packing the soil around the roots until the hole is filled. Potted trees can be planted at any time of the year. However, if they are root-bound, it is best to plant them when dormant. That way the soil can be shaken off the roots, the roots can be spread out into hole and pruned if necessary, and one can avoid overstressing the tree during the growing season. Just after planting, it is important to water in the tree. A gallon or more per tree is needed, depending on the size. Maintain a weed-free zone around the tree using herbicide, shallow cultivation, or mulching.

\section{Irrigation}

Providing newly planted trees with adequate water is critical for establishment, especially in bare-root plantings, because transplanting shock can be quite a setback for young persimmons. Frequent irrigation ( 2 to 4 times per week) is required after planting. The quantity of irrigation will be determined by several factors, including rainfall, soil type, and evapotranspiration levels. Microsprinklers and drip irrigation are effective means to supply water and can also be used for fertigation.

As a persimmon tree matures, it will become more tolerant of occasional drought conditions, especially on the D. virginiana rootstock. It is still essential that water is available 
to the trees during their main growth phase in the first few months of the season. Overwatering encourages vegetative growth during the flowering and fruiting stage, and it can result in increased fruit shedding. Recent research with regulated deficit irrigation (RDI) has shown the opposite effect by reducing fruit drop when applied early in the season. However, this can cause smaller fruit at harvest time. When RDI was applied later in the season, fruit color development took place earlier. There is still more to discover on using irrigation to influence persimmon fruiting habits.

\section{Fertilization}

Small-scale demonstration or research plots with persimmons were established in 5 or more locations during the 1980s and 90s in Florida. However, these trials mostly followed common guidelines for fruit trees regarding fertilization practices, so little Florida-specific information of nutrient requirements and timing is currently known.

A general recommendation, based upon what has been done in Florida and common production practices of Japan, is listed in Table 1. It is important to note that a split fertilization plan with 3 applications is recommended, with $50 \%$ applied in late dormancy (March) and 25\% each in June and September. A balanced fertilizer including macroand micronutrients is suggested. The amount used in year 10 can be applied in succeeding years. Magnesium deficiencies can occur if soil potassium or calcium levels are too high, and manganese and iron can be scarce in soils with a $\mathrm{pH}$ above 7 . Heavy applications of quick-release nitrogen should be avoided because this can increase fruit drop.

\section{Training and Pruning Modified Central Leader}

This is the most common training system currently used, and it closely approaches the natural form of the tree. In this training method, a recently planted dormant tree is cut back to approximately two and a half feet, which is usually just a single stem coming from the ground. In the second winter pruning, the main central leader that grew after the first pruning is cut back by $1 / 3$. By this time, there will be some lateral branching beginning. Select one of the laterals with a wide crotch angle growing at about the two-anda-half-foot mark as the first main branch. Branch spacers can also be used to help widen branch angles. If present, select another branch about 8-12 inches above the first branch that is angling in another direction, and remove any branches on the trunk between the first and second. Each succeeding winter pruning continues the process of cutting the central leader back by $1 / 3$ and selecting additional laterals every $8-12$ inches to keep. The goal is to have 4-6 well-spaced branches radiating from the trunk. Once this is achieved, the central leader is then "modified" by cutting it back to the final lateral branch, which will limit significant height increases in the future (Figure 3).

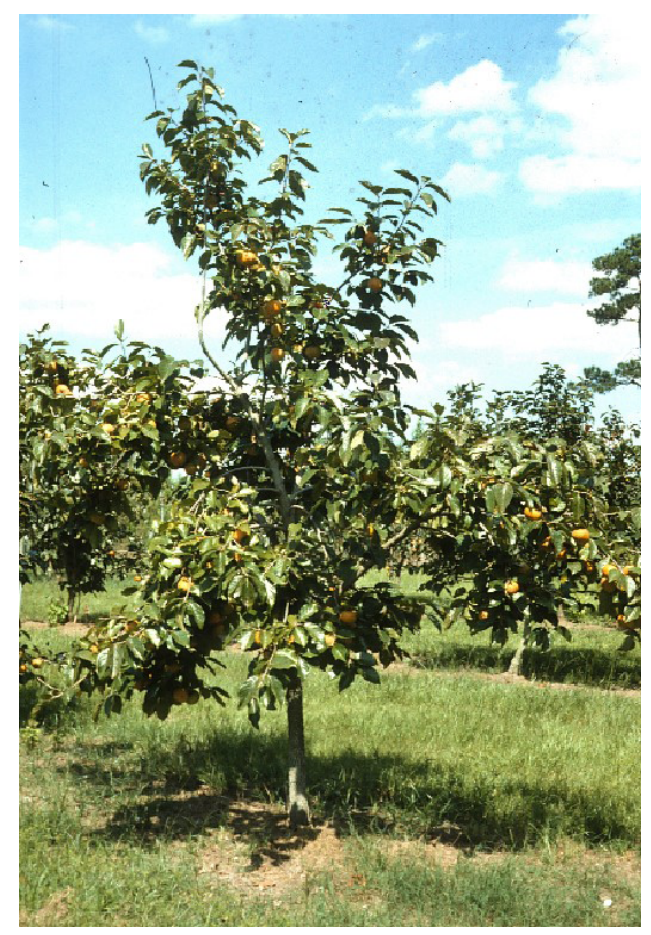

Figure 3. Modified central leader system. Credits: UF/IFAS

\section{Palmette System}

This system requires the use of a tall trellis; however, it can double the number of trees per acre, with up to 290 trees on a $15 \mathrm{ft}$ in-row spacing and $10 \mathrm{ft}$ between rows. The number of horizontal wires varies, but 3 to 4 is common. The bottom wire is placed around 40 inches from the ground, with additional wires added every $3 \mathrm{ft}$. Two opposite-facing limbs in line with the trellis around $2 \mathrm{ft}$ from the ground are chosen as the first branches and are attached to the trellis positioned at an upward angle of 45 degrees. Branch spreaders can also be used in this process. Moving up the centrally growing trunk, opposite-facing branch pairs every $2 \mathrm{ft}$ are attached to the trellis to make the next tier of growth. Visually this system will produce a flattened vertical canopy resembling a feather. A trellis also offers the opportunity to use it as a structure for frost protection using blanket material or netting for preventing bird damage.

\section{Other Systems}

Many additional training methods exist, such as the opencentered, Y-shaped, or variations of trellis designs. Recent research investigations into a horizontal training system showed higher yield potential and reduced need for ladders 
due to a shorter canopy. Root zone restriction techniques can allow very high density plantings upward of $1500+$ trees per acre, but long-term prospects are still unknown. When choosing a training system, cost versus benefit should always be considered.

\section{General Pruning}

Heavy pruning of persimmon is often not required or beneficial. When the main structural branches are in place, some are lightly pruned and tipped each season to stimulate more branching, while others are left unpruned. After several years of this type of pruning, the fruiting areas will get farther away from the trunk, and branch density will increase. Some of these dense areas will need to be thinned out occasionally in order to make sure light distribution within the canopy remains adequate. Any branches that do not fit the training system being used can be pruned back more or removed, and the sooner the better.

\section{Flowering and Fruiting}

\section{Flowering}

Persimmons flower and produce fruit on shoots (current season's growth) several weeks after vegetative bud break. Many of the commonly grown varieties produce female flowers (Figures 4 and 6). These occur singularly and are easily identified by the large four-lobed calyx surrounding them, which plays an important role in fruit development. Male flowers are smaller and grow in clusters on small stems (Figure 5). Persimmons can set modest crops parthenocarpically (without fertilization). However, including an occasional pollinizer tree in the planting will provide maximum yield. A ratio of 1:15 (pollinizer to main variety) was used in a demonstration trial in Florida, and although this ratio produced excessive fruit set, it can also help prevent excessive fruit drop to ensure a good crop. A ratio between 1:15 and 1:40 is suggested for Florida. 'Gailey' and 'Nishimura' are the most frequently used pollinators known for their abundance of male flowers (for more information about pollination and cultivars visit Japanese Persimmon Cultivars in Florida at https://edis.ifas.ufl.edu/mg242).

\section{Fruiting}

An initial fruit drop commonly occurs following petal fall. The extent of the drop depends on multiple factors, such as previous season crop load, pollination, water and nutrient excesses, and lack of light infiltration into the canopy. Subsequent fruit drops can also occur in June and later, but they are normally lighter. Pollination lowers the amount of fruit drop, but by increasing the fruit load, more fruit thinning will be needed to bring the crop to a sustainable level, because persimmons tend toward biennial bearing if fruit load is high. Mature trees of smaller-fruited cultivars may reasonably support 250-300 fruit per tree at maturity, whereas larger-fruited cultivars could handle 150-200 fruit per tree. Trees will begin bearing fruit by the third year, with 8-10 years required for full production. Recent production data from 2013-2014 in California shows the average persimmon yield is 5.4 tons per acre. Estimates of production in south Florida are in the 3.6-5.4 tons per acre range, and north Florida is likely on the higher end. Yields are generally lower for the nonastringent varieties.

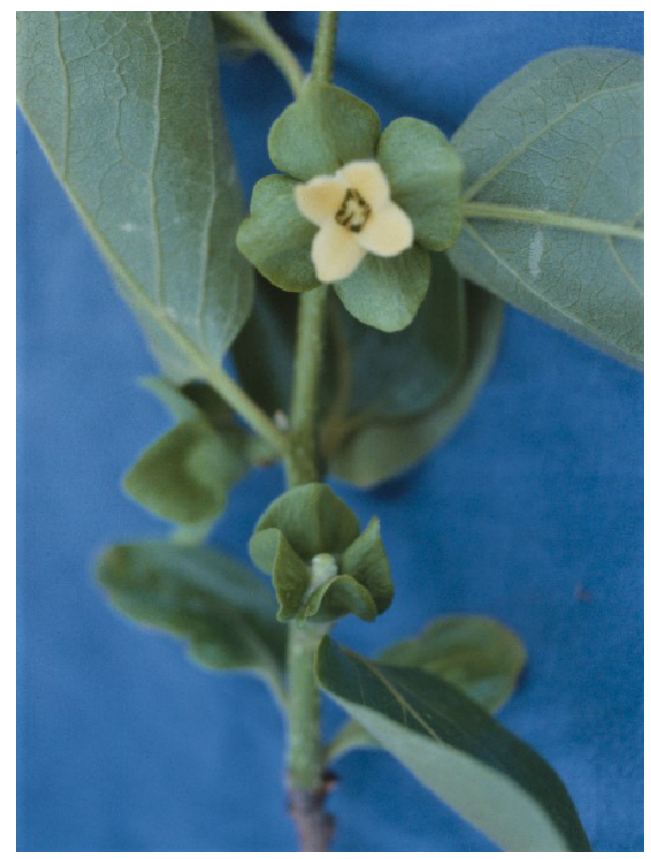

Figure 4. Female persimmon flower. Credits: UF/IFAS

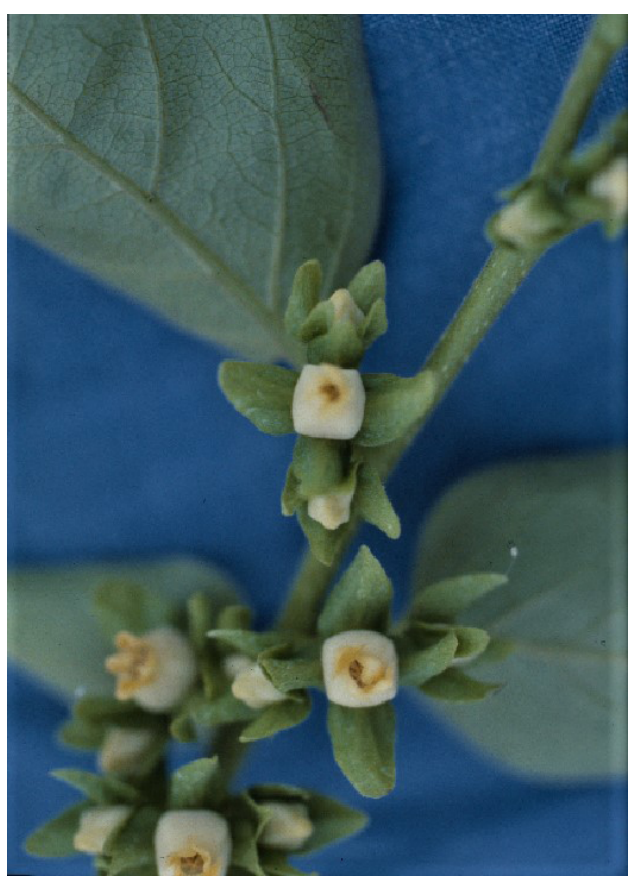

Figure 5. Male persimmon flowers. Credits: UF/IFAS 


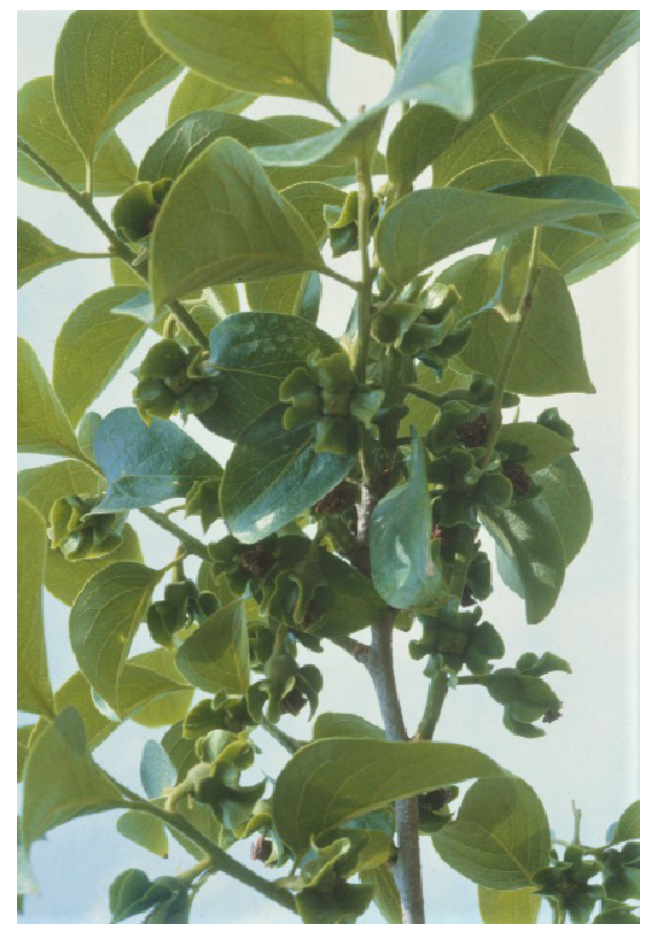

Figure 6. Persimmon shoots with flowers.

Credits: UF/IFAS

\section{Fruit Thinning}

Thinning persimmon fruit is often needed to regulate the crop load (Figure 7) and to help limit the alternate bearing tendency. Some regulation of crop load can be made through judicious pruning during the winter. Most flower buds will grow from the few end buds on a branch tip. By leaving some of these unpruned, some tipped a bud or two, and other weak branches pruned back further, less thinning of fruit is required. Hand thinning is done just after the first natural fruit drop, or about 3 weeks after flowering. Fruit should be spaced 6 inches apart on a branch to prevent rubbing damage to adjacent fruit. Remove any deformed or damaged fruit, and leave the fruit with the largest calyxes for the best fruit quality at harvest.

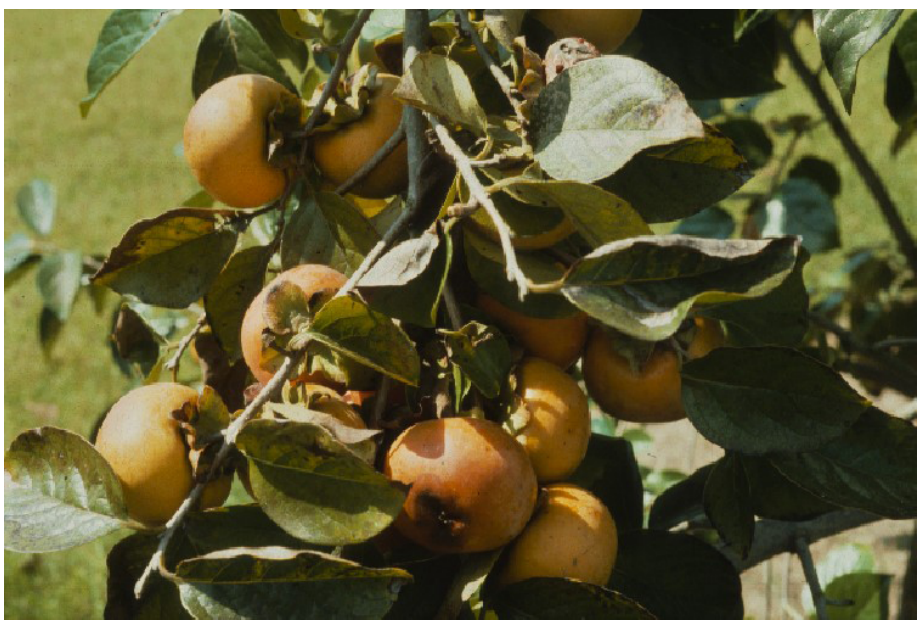

Figure 7. Very heavy crop load, unthinned.

Credits: UF/IFAS

\section{Harvest and Postharvest}

The ripening season for persimmons varies by cultivar and runs from August through December. Nonastringent types can be picked when firm, beginning in the yellow/orange phase through full color. Astringent types should be picked at full color, when soft or nearing softness. Clip the fruit from the tree in order to prevent damage to the fruit and branches that could occur from twisting and pulling.

Nonastringent types tend to have a longer shelf life compared to astringent types, especially those that have had the astringency artificially removed. At room temperature, a nonastringent type, such as 'Fuyu', can last up to 30 days. Shelf life can be prolonged to 2 months in $0^{\circ} \mathrm{C}$ storage, and up to 6 months in controlled atmosphere conditions.

\section{Bud Break and Freeze Damage}

As with most fruit crops grown in areas where late winter and early spring freeze events occur, cold damage to newly growing persimmon buds and shoots can happen (Figure 8). Although persimmons lack a high chilling requirement, they do require a moderate amount of heat accumulation in order to begin growth. This makes them late to leaf out, compared with peaches, blueberries, and pears. If warm weather occurs for an extended period in January and February without frosts, growth can begin. Site selection away from low areas, maintaining proper nutrient levels, and limiting overproduction of fruit are practices to help decrease the chances of cold damage and improve the tree's tolerance to stress. If growth has begun, overhead irrigation at a rate of $1 / 4$ inch per hour to coat the tree with ice during a calm night below $32^{\circ} \mathrm{F}$ is also an effective protective measure. Damage can occur at the bud break stage at $27^{\circ} \mathrm{F}$ for a 1-hour duration. Generally, early-spring frost damage to reproductive buds of persimmon is minimized by the fact that flower buds open on new vegetative shoots after they have been growing for several weeks.

\section{Pests and Diseases of Persimmons}

Table 3 and Table 4 show the most common pests and diseases of Japanese persimmons in Florida, their symptoms, and how to control them. 


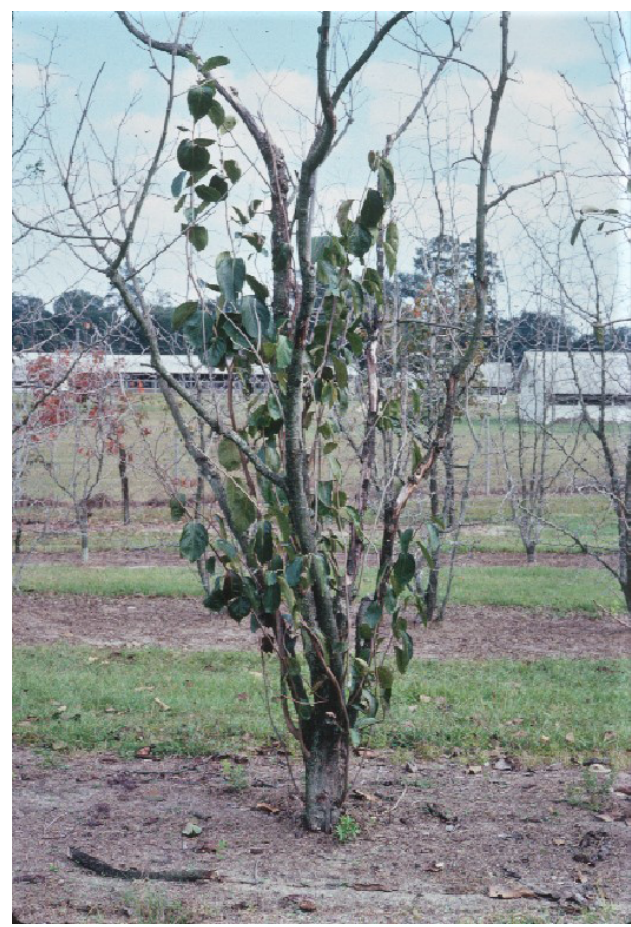

Figure 8. Freeze damage and regrowth from dormant buds. Credits: UF/IFAS

\section{References}

Andersen, P. C., K. R. Athearn, A. Sarkhosh, M. A. Olmstead, and J. G. Williamson. 2020. Sustainability Assessment of Fruit and Nut Crops in North Florida and North Central Florida. HS765. Gainesville: University of Florida Institute of Food and Agricultural Sciences. https://edis.ifas.ufl.edu/ mg367

Ben-Arie, R., S. Zilkah, I. Klein, and D. Gamrasni. 2008. "Persimmon and Environment: Soil and Water Management for High Quality Fruit Production." Advances in Horticultural Science 22 (4): 286-293.

Branscome, D. 2012. White Peach Scale, Pseudaulacaspis pentagona (Targioni) (Insecta: Hemiptera: Diaspididae). EENY-076. Gainesville: University of Florida Institute of Food and Agricultural Sciences. https://edis.ifas.ufl.edu/ in 233

Crane, J. H., and C. F. Balerdi. 1997. "Estimated Crop Yields of Tropical Fruit Crops under South Florida Conditions." https://sfyl.ifas.ufl.edu/media/sfylifasufledu/miami-dade/ documents/tropical-fruit/Crop-yields-per-tree-andacre-2010.pdf

Crocker, T. E., J. G. Williamson, and J. L. Jackson. 1996. "Demonstration Plots of Alternate Fruit and Nut Crops for Central Florida." Proceedings of the Florida State Horticultural Society 109:209-211.
Davies, F. T., R. L. Geneve, D. E. Kester, and H. T. Hartmann. 2011. Hartmann and Kester's Plant Propagation: Principles and Practice. Upper Saddle River, NJ: Prentice Hall.

Frank, S., J. Baker, and S. Bambara. 2019. “Twig Girdler.” NC State Extension. https://content.ces.ncsu.edu/ twig-girdler-1

George, A., B. Nissen, R. Broadley, R. Collins, P. Rigden, S. Jeffers, B. Isaacson, S. Ledger, N. Vock, and L. Chapman. 2005. Sweet Persimmon Information Kit. Agrilink, Your Growing Guide to Better Farming Guide. Agrilink Series Q105102. Brisbane, Australia: Queensland Department of Agriculture, Forestry, and Fisheries. 168.

Gomez, C., and R. F. Mizell. 2019. Green Stink Bug, Chinavia halaris (Say) (Insecta: Hemiptera: Pentatomidae). EENY-431. Gainesville: University of Florida Institute of Food and Agricultural Sciences. https://edis.ifas.ufl.edu/ in794

Intrigliolo, D. S., L. Bonet, E. Badal, C. Besada, and A. Salvador. 2012. "Regulated Deficit Irrigation of 'Rojo Brillante' Persimmon (Dyospyros kaki) Yield, Fruit Quality and Post-harvest Performance." VII International Symposium on Irrigation of Horticultural Crops 1038:415-422.

Jackson, D., N. E. Looney, and M. Morley-Bunker, eds. 2011. Temperate and Subtropical Fruit Production. CABI. 260-265.

Kim, W. S., S. J. Chung, K. Y. Kim, T. DeJong, and H. S. Choi. 2002. "Relationships between $\mathrm{Ca}, \mathrm{K}$ and Mg Concentration and Browning of Blossom End Part of 'Fuyu' Sweet Persimmon during MA Storage." Advances in Horticultural Science 16 (2): 95-100.

Kitagawa, H., and P. Glucina. 1984. Persimmon Culture in New Zealand. Wellington, New Zealand: Science Information Publishing Center, DSIR.

Lamborn, A. R. 2017. "Persimmon.” https://sfyl.ifas.ufl.edu/ media/sfylifasufledu/baker/docs/pdf/horticulture/educatorresources/Persimmon.pdf

McRitchie, J. J. 1979. Cephalosporium Wilt of Persimmon. Plant Pathology Circular No. 197. Fla. Dept. Agric. \& Consumer Serv. Division of Plant Industry. 
Mead, F. W. 1966. Persimmon psylla. Entomology Circular No. 50. Florida Department of Agriculture, Division of Plant Industry.

Mizell, R. F., III and G. Brinen. 2015. Insect Management in Oriental Persimmon. ENY-803. Gainesville: University of Florida Institute of Food and Agricultural Sciences. https:// edis.ifas.ufl.edu/ig096

Mizell, R. F., III. 2018. Peachtree Borers in the Home and Commercial Peach Orchard. ENY-691. Gainesville: University of Florida Institute of Food and Agricultural Sciences. https://edis.ifas.ufl.edu/in489

Mizell, R. F., III. 2019. The Persimmon Borer Sannina uroceriformis Walker, Pest of Persimmon. ENY-835. Gainesville: University of Florida Institute of Food and Agricultural Sciences. https://edis.ifas.ufl.edu/in669

Mowat, A. D. 1993. "The Effect of Root Temperature on Bud Dormancy Release of Persimmon (Diospyros kaki L.)." IV International Symposium on Growing Temperate Zone Fruits in the Tropics and in the Subtropics 409:137-140.

Mowat, A. D., R. J. Collins, and A. P. George. 1993. "Cultivation of Persimmon (Diospyros kaki L.) under Tropical Conditions." IV International Symposium on Growing Temperate Zone Fruits in the Tropics and in the Subtropics 409:141-150.

Sharpe, R. H. 1966. "Persimmon Variety and Rootstock Observation." Proceedings of the Florida State Horticultural Society 79:374-378.

Tetsumura, T. 2001. "Production and Field Evaluation of Own-Rooted Trees of Japanese Persimmon (Diospyros kaki Thunb.)." PhD diss., Kyoto University.

Tetsumura, T., S. Ishimura, T. Takita, S. Funaki, H. Uchida, T. Hidaka, S. Haranoushiro, Y. Udatsu, M. Matsuo, C. Honsho, and H. Asakuma. 2019. "Tree Growth, Flowering, and Fruiting of 'Taishuu'Japanese Persimmon Grafted onto Dwarfing Rootstocks." The Horticulture Journal 88 (1): 57-66.

Tetsumura, T., R. Tao, and A. Sugiura. 2000. "Single-Node Stem Cuttings from Root Suckers to Propagate a Potentially Dwarfing Rootstock for Japanese Persimmon." HortTechnology 10 (4): 776-780.

Yakushiji, H., A. Azuma, H. Sugiura, A. Yamasaki, and Y. Koshita. 2014. "Comparison of Promising Dwarfing
Rootstocks for 'Fuyu' Japanese Persimmon Trees.” XXIX International Horticultural Congress on Horticulture: Sustaining Lives, Livelihoods and Landscapes (IHC2014) 1130:469-472.

Yakushiji, H., and A. Nakatsuka. 2007. "Recent Persimmon Research in Japan." Jpn. J. Plant Sci 1 (2): 42-62.

Yamada, M. 2008. "Persimmon Propagation, Orchard Planting, Training and Pruning in Japan." Advances in Horticultural Science 22 (4): 269-273. 
Table 1. Application time and amount (Ib) of 10-10-10 with micronutrients.

\begin{tabular}{|c|c|c|c|c|}
\hline Year & March (dormant) & June & September & Total applied \\
\hline 1 & 0.5 & 0.25 & 0.25 & 1 \\
\hline 2 & 0.875 & 0.4375 & 0.4375 & 1.75 \\
\hline 3 & 1.25 & 0.625 & 0.625 & 2.5 \\
\hline 4 & 1.625 & 0.8125 & 0.8125 & 3.25 \\
\hline 5 & 2 & 1 & 1 & 4 \\
\hline 6 & 2.375 & 1.1875 & 1.1875 & 4.75 \\
\hline 7 & 2.75 & 1.375 & 1.375 & 5.5 \\
\hline 8 & 3.125 & 1.5625 & 1.5625 & 6.25 \\
\hline 9 & 3.5 & 1.75 & 1.75 & 7 \\
\hline 10 & 3.875 & 1.9375 & 1.9375 & 7.75 \\
\hline
\end{tabular}

Table 2. Leaf nutrient ranges of high-yielding persimmon trees in Japan.

\begin{tabular}{|l|c|l|}
\hline Element & Leaf tissue concentration (\%) & Role in the tree \\
\hline Nitrogen & $2.22-3.15$ & Increase flower production \\
\hline Phosphorus & $0.11-0.16$ & Enhance fruit color, root development \\
\hline Potassium & $1.47-3.86$ & Promote shoot growth, fruit weight, water regulation \\
\hline Calcium & $0.92-2.78$ & Prevent shoot deformities, improve shelf life \\
\hline Magnesium & $0.22-0.77$ & Production of seed, phosphorus transport \\
\hline
\end{tabular}


Table 3. Major insect pests of Japanese persimmons in Florida.

\begin{tabular}{|c|c|c|}
\hline Insect Pests & Symptoms & Control \\
\hline $\begin{array}{l}\text { Scale (Figures } 9,10) \\
\text { primarily white peach scale } \\
\text { (Pseudaulacaspis pentagona) }\end{array}$ & $\begin{array}{l}\text { Snow-white patches on trunk and limbs, } \\
\text { easily scraped off. Most visible when males } \\
\text { emerge during warm weather. }\end{array}$ & $\begin{array}{l}\text { 3\% dormant oil applied before bud break, summer oil, or } \\
\text { two pesticide applications 1-2 weeks apart (imidacloprid, } \\
\text { MOA 4A, such as Provado 1.6F; potassium salt such as Safer } \\
\text { soap; or Scalecide); ladybird beetles and lacewings for } \\
\text { biological control. }\end{array}$ \\
\hline $\begin{array}{l}\text { Persimmon psylla (Figures 11, } \\
\text { 12) (Trioza diospyri) }\end{array}$ & $\begin{array}{l}\text { Crinkled and deformed young leaves, } \\
\text { stunted growth. White-colored nymphs } \\
\text { found within distorted leaves and black- } \\
\text { bodied adults on leaf surface. Mealy bugs } \\
\text { may also be present. }\end{array}$ & $\begin{array}{l}\text { Best to control very early; sprays less effective when leaves } \\
\text { curl. Many pesticide options. May also need to control the } \\
\text { ants that feed on the honeydew. }\end{array}$ \\
\hline $\begin{array}{l}\text { Twig girdler } \\
\text { (Oncideres cingulata) }\end{array}$ & $\begin{array}{l}\text { Girdled limbs present on trees or that } \\
\text { have broken and fallen to the ground with } \\
\text { leaves attached. Twig girdler may also } \\
\text { transmit wilt disease. }\end{array}$ & $\begin{array}{l}\text { Girdled limbs removed to prevent pest buildup. Best to } \\
\text { apply preventative spray in fall, when egg laying occurs. } \\
\text { Pyrethroids, MOA 3A, such as Pyrenone Crop Spray. }\end{array}$ \\
\hline $\begin{array}{l}\text { Tree borers (Figures } 13,14 \text { ) } \\
\text { (multiple species, including } \\
\text { Sannina uroceriformis) }\end{array}$ & $\begin{array}{l}\text { Gummy sap, frass, or sawdust coming from } \\
\text { small holes in bark, pruning cuts, or trunk } \\
\text { near soil line. }\end{array}$ & $\begin{array}{l}\text { March through June applications best to prevent larvae } \\
\text { from entering tree. Limited direct control information; } \\
\text { controls for peachtree borer may be effective (imidacloprid). }\end{array}$ \\
\hline $\begin{array}{l}\text { Stink bugs (Figure 15) } \\
\text { (multiple in family Pentatomidae) }\end{array}$ & $\begin{array}{l}\text { Damage shows up as off-white sections of } \\
\text { fruit during color development, and areas } \\
\text { may decay. Only an issue on nonastringent } \\
\text { cultivars. }\end{array}$ & $\begin{array}{l}\text { Certain life stages may be parasitized by wasps or flies for } \\
\text { biological control. Chemical control: Pyrethroids, MOA 3A, } \\
\text { such as Pyrenone Crop Spray. }\end{array}$ \\
\hline $\begin{array}{l}\text { Thrips } \\
\text { (multiple species) }\end{array}$ & $\begin{array}{l}\text { Fruit may be affected in south Florida. } \\
\text { Thrips are often seen around fruit set and } \\
\text { flowering and may cause fruit deformities. }\end{array}$ & $\begin{array}{l}\text { Sprays best around early fruit development (Bonide } \\
\text { Rotenone/Pyrethrin, Pyrellin, Pyrenone Crop Spray). }\end{array}$ \\
\hline $\begin{array}{l}\text { Caterpillars } \\
\text { (Malacosoma disstria) } \\
\text { Scarab beetles } \\
\text { (Phyllophaga spp.) }\end{array}$ & $\begin{array}{l}\text { Forest tent caterpillar and scarab beetles } \\
\text { can feed on leaves early in the season. } \\
\text { Fall webworms can also impact the later } \\
\text { season. }\end{array}$ & $\begin{array}{l}\text { Appropriate timing of sprays in spring and fall when } \\
\text { present. }\end{array}$ \\
\hline
\end{tabular}

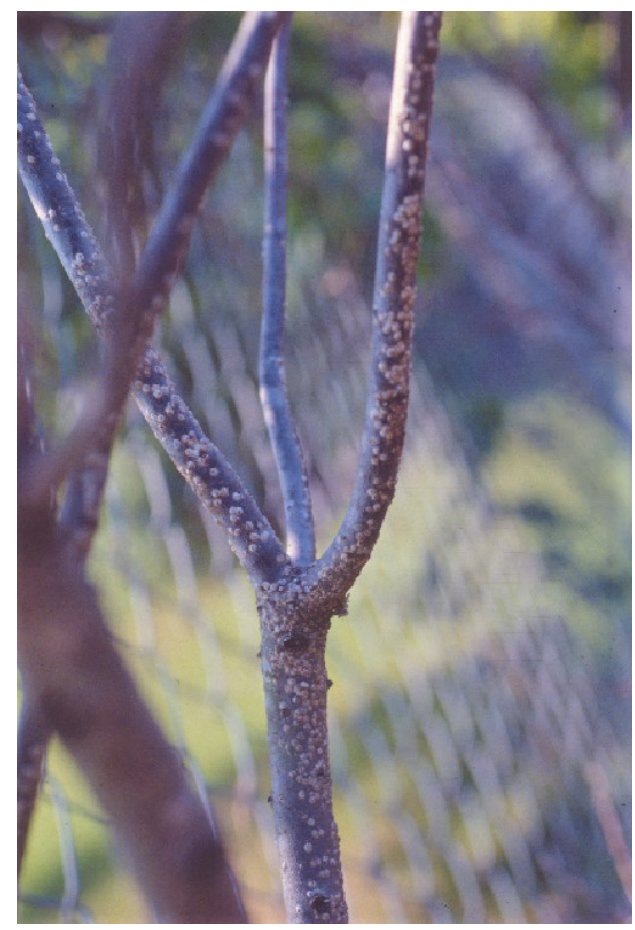

Figure 9. Scale on persimmon.

Credits: UF/IFAS

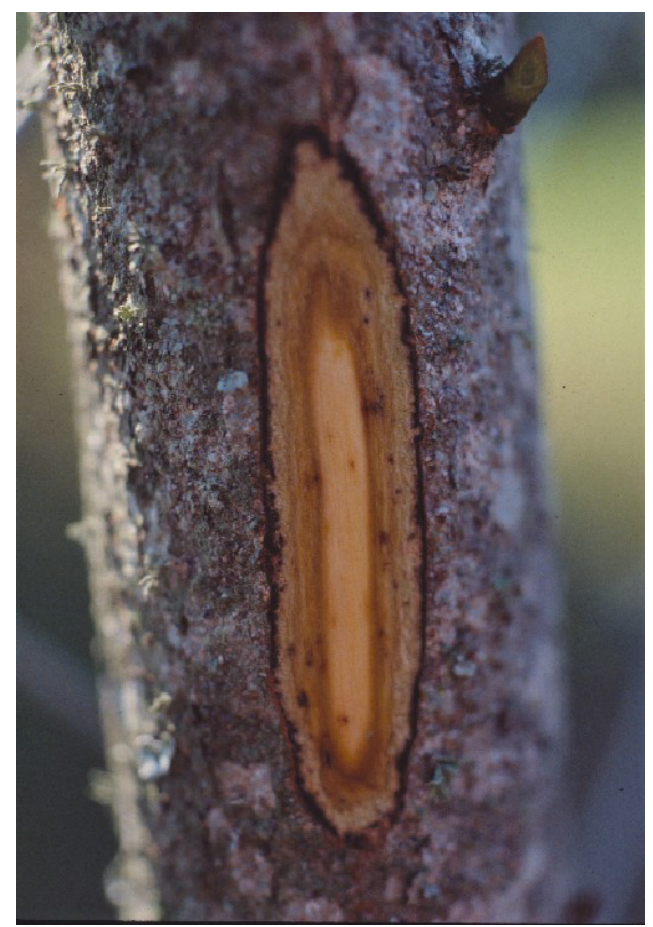

Figure 10. Damage from scale under the bark. Credits: UF/IFAS 


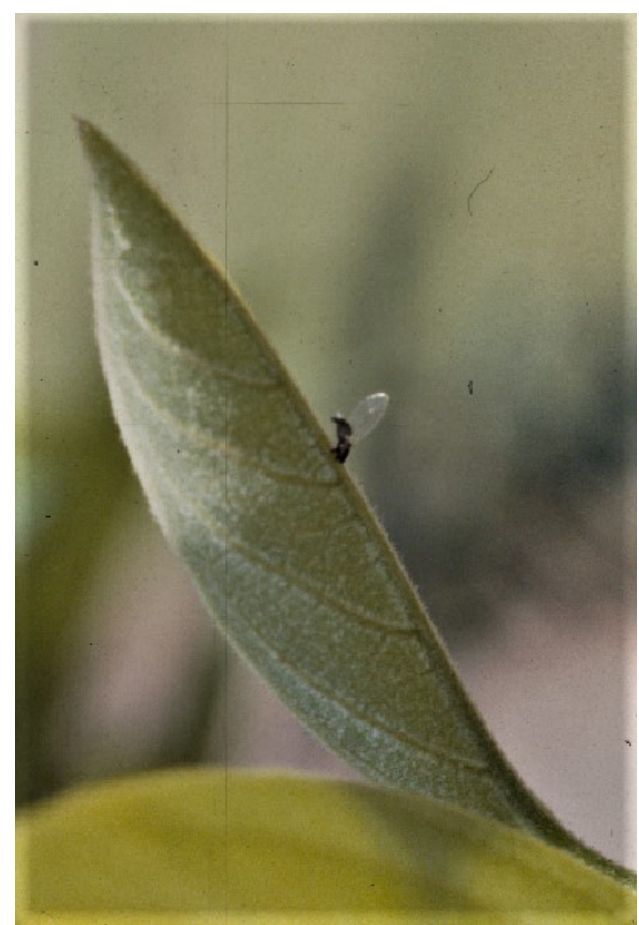

Figure 11. Adult persimmon psylla on leaf. Credits: UF/IFAS

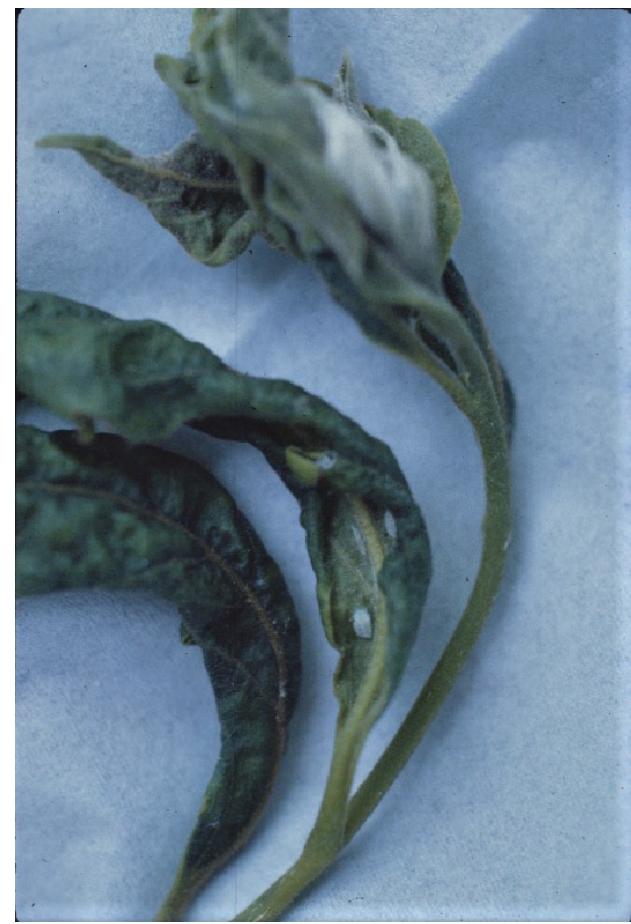

Figure 12. Psylla nymphs on distorted leaves.

Credits: UF/IFAS

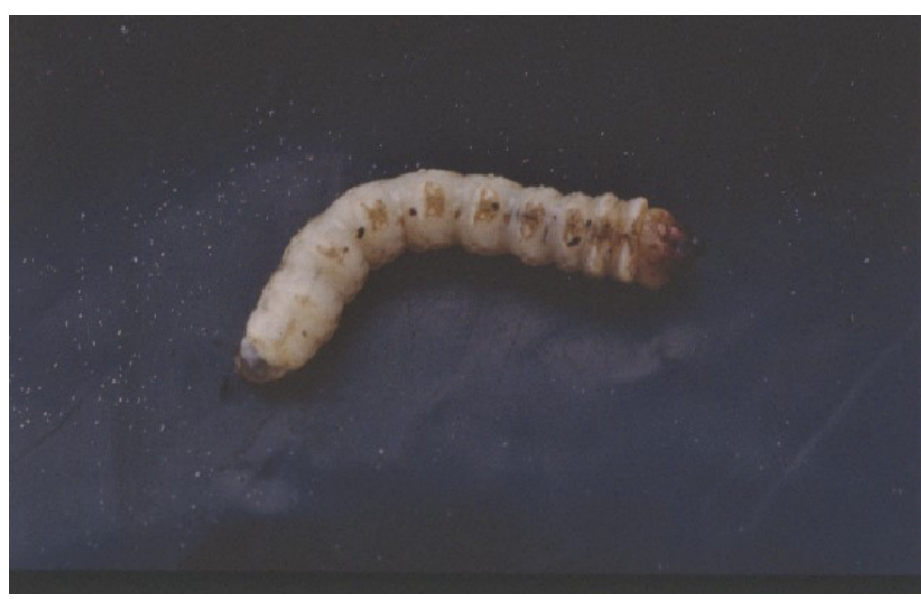

Figure 13. Tree borer of persimmon.

Credits: UF/IFAS

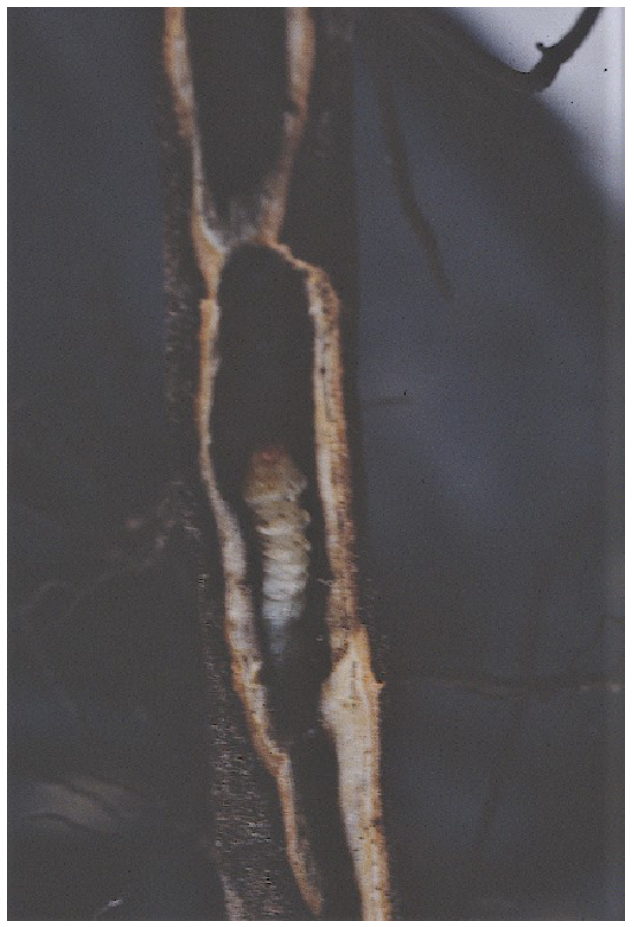

Figure 14. Tree borer inside the root.

Credits: UF/IFAS

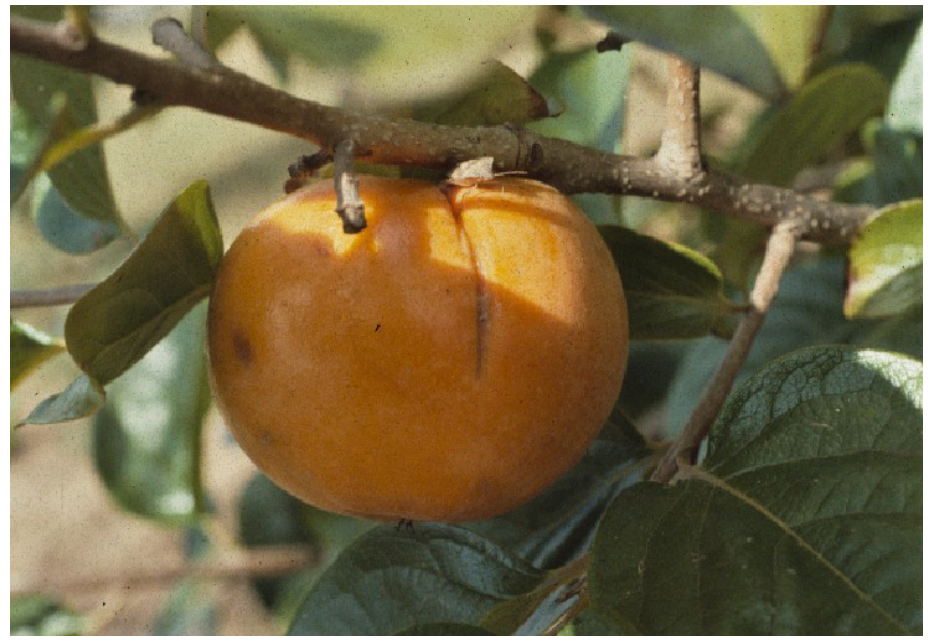

Figure 15. Stink bug on persimmon fruit.

Credits: UF/IFAS 
Table 4. Major diseases of Japanese persimmons in Florida.

\begin{tabular}{|c|c|c|}
\hline Diseases & Symptoms & Control \\
\hline $\begin{array}{l}\text { Botryosphaeria canker } \\
\text { (Figure 23) } \\
\text { (Botryosphaeria dothidea, B. } \\
\text { rhodinina, B. obtusa, and B. ribis) }\end{array}$ & $\begin{array}{l}\text { Discoloration of wood and deep, elongated } \\
\text { bark scars may be present. This disease is the } \\
\text { limiting factor for growing persimmons in } \\
\text { Florida and the Deep South. Often this fungus } \\
\text { limits the lifetime of Japanese persimmons to } \\
\text { about } 8 \text { to } 12 \text { years (or less). }\end{array}$ & $\begin{array}{l}\text { There is no good chemical control. Pruning to wide } \\
\text { crotch angles, pruning during dry days, disinfecting tools, } \\
\text { maintaining good airflow in the canopy, reducing water or } \\
\text { nutrient stress to trees, and a good fungicide program are } \\
\text { recommended to help reduce the incidence of this fungus. }\end{array}$ \\
\hline $\begin{array}{l}\text { Leaf and fruit spots } \\
\text { (Figure } 16-21 \text { ) } \\
\text { (Cercospora spp., Alternaria } \\
\text { spp., Gloeosporium spp., } \\
\text { Phyllosticta spp., Botrytis } \\
\text { cinerea, Pseudomonas syringae, } \\
\text { Colletotrichum sp., Ramularia sp.) }\end{array}$ & $\begin{array}{l}\text { Cercospora: leaf spots and early defoliation. } \\
\text { Gloeosporium: anthracnose "bitter rot" that } \\
\text { affects fruit and shoots. } \\
\text { Colletotrichum: affects ripening fruit. } \\
\text { Ramularia: leaf spots sometimes in mid- } \\
\text { season. } \\
\text { Botrytis: brown leaf patches. } \\
\text { Pseudomonas: "bacterial blast" leaf spots and } \\
\text { blackened stem and leaf petioles. }\end{array}$ & $\begin{array}{l}\text { Proactive fungicide sprays in early season, and cover } \\
\text { sprays in summer in rotation. }\end{array}$ \\
\hline $\begin{array}{l}\text { Persimmon wilt (Figure 22) } \\
\text { (Cephalosporium diospyri) }\end{array}$ & $\begin{array}{l}D \text {. virginiana rootstock is susceptible to this } \\
\text { disease; } D \text {. kaki and } D \text {. lotus are immune. If the } \\
D \text {. kaki scion is carrying the pathogen, it can } \\
\text { move into the native rootstock and kill the } \\
\text { tree. Symptoms include wilting and tree top } \\
\text { death. }\end{array}$ & $\begin{array}{l}\text { Use clean scion material when propagating, remove } \\
\text { infected plants quickly, and sanitize pruning tools } \\
\text { between trees. }\end{array}$ \\
\hline $\begin{array}{l}\text { Phomopsis spp., Verticillium } \\
\text { albo-atrum, Botryosphaeria } \\
\text { dothidea (Figures } 23,24 \text { ) }\end{array}$ & $\begin{array}{l}\text { May cause small leaves and fruit, and terminal } \\
\text { twigs that are leafless. May also cause wilting, } \\
\text { shoot decline, and bark cracking at limb } \\
\text { joints. }\end{array}$ & \\
\hline
\end{tabular}

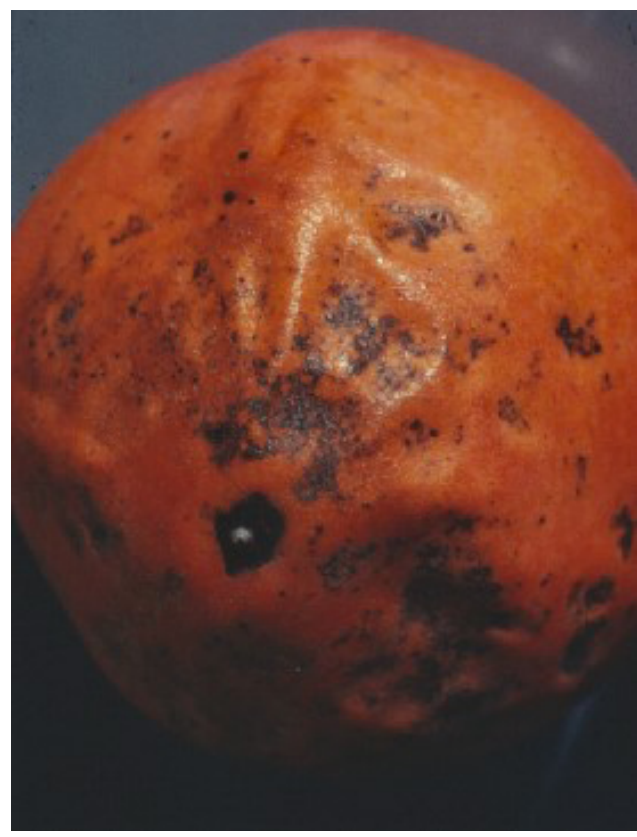

Figure 16. Fruit spotting on persimmon.

Credits: UF/IFAS

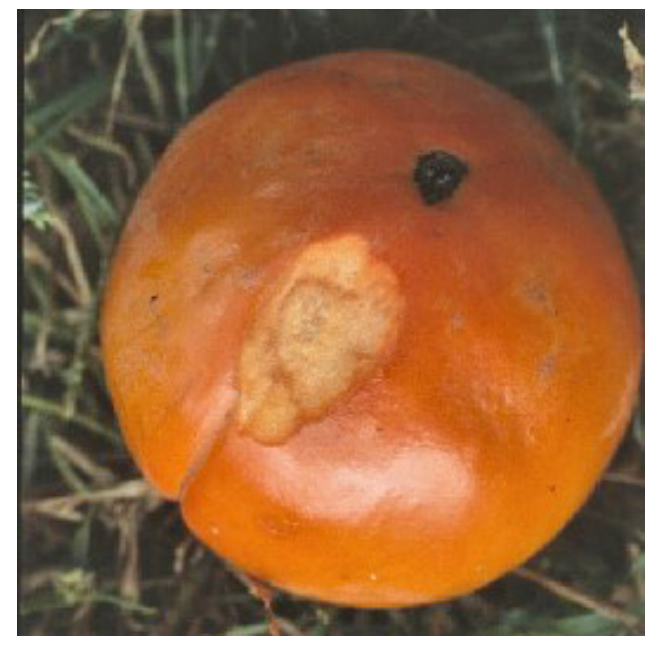

Figure 17. Anthracnose on persimmon fruit. Credits: UF/IFAS

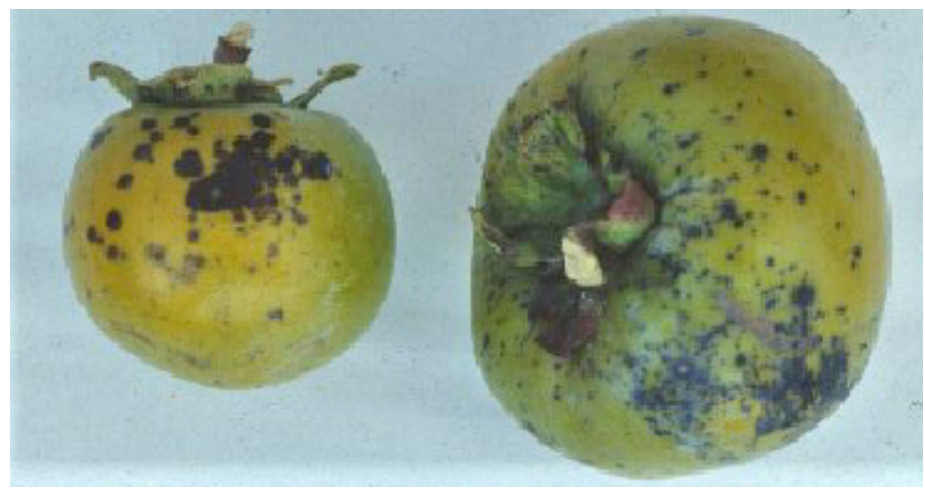

Figure 18. Anthracnose on persimmon fruit. Credits: UF/IFAS 


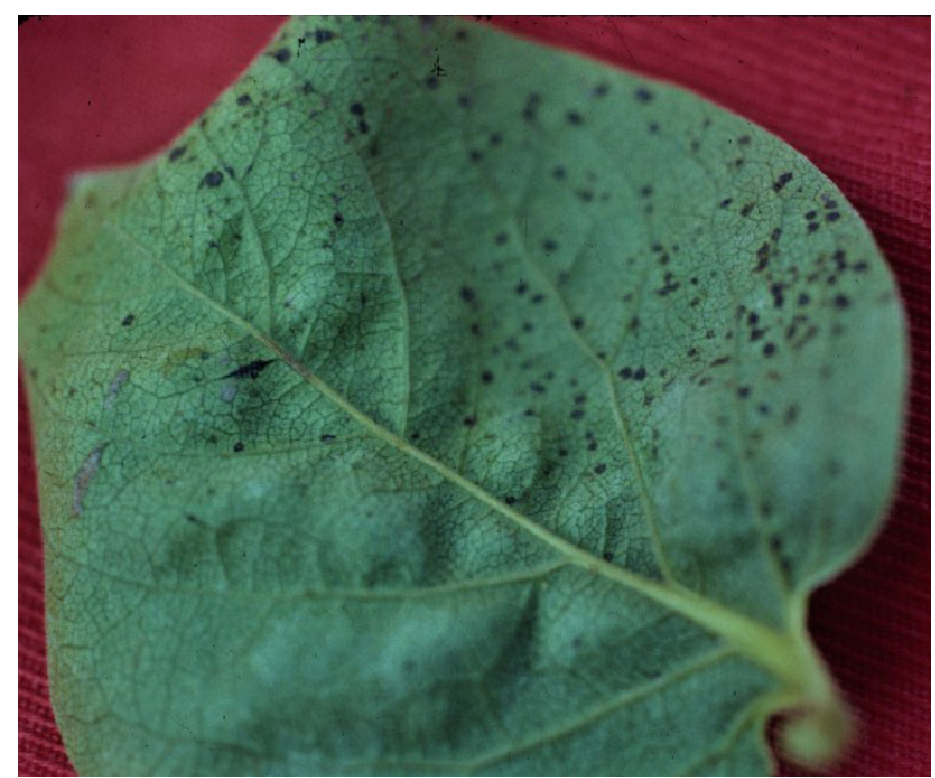

Figure 19. Persimmon leaf spotting.

Credits: UF/IFAS

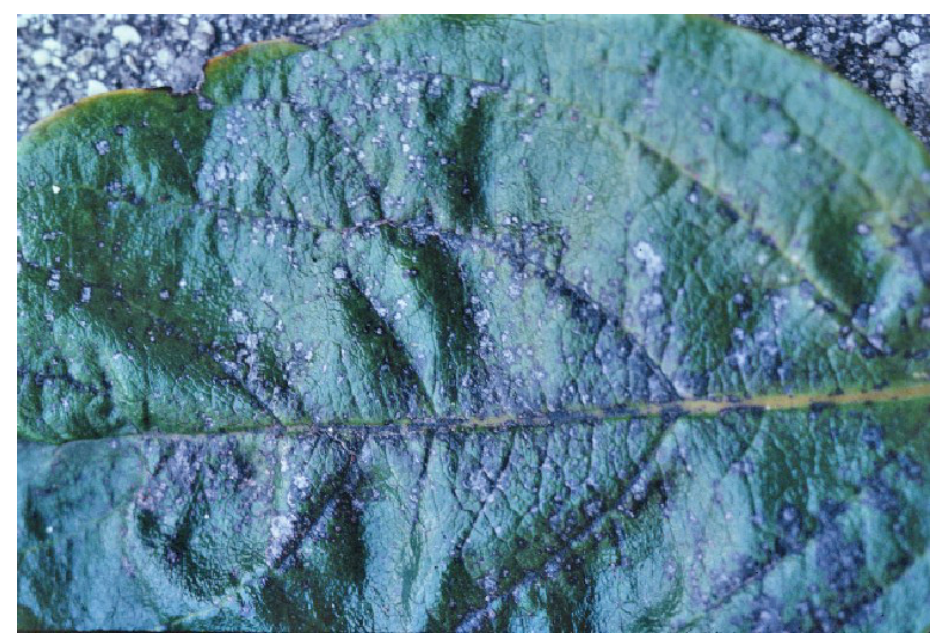

Figure 20. Phyllosticta spotting on persimmon leaf.

Credits: UF/IFAS

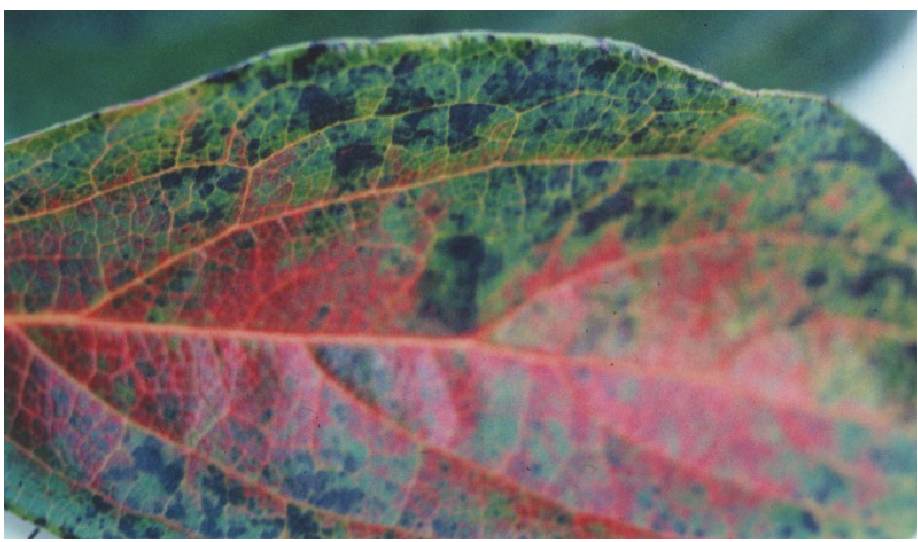

Figure 21. Alternaria spotting on persimmon leaf.

Credits: UF/IFAS

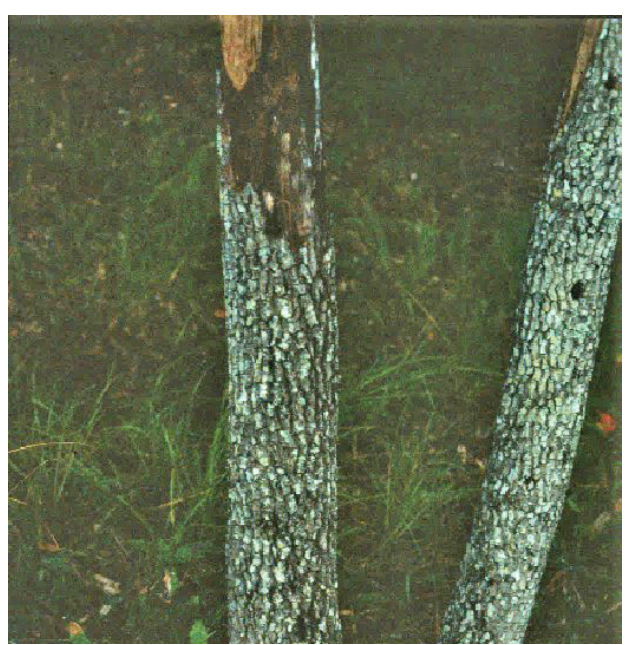

Figure 22. Cephalosporium damage on persimmon trunk. Credits: UF/IFAS

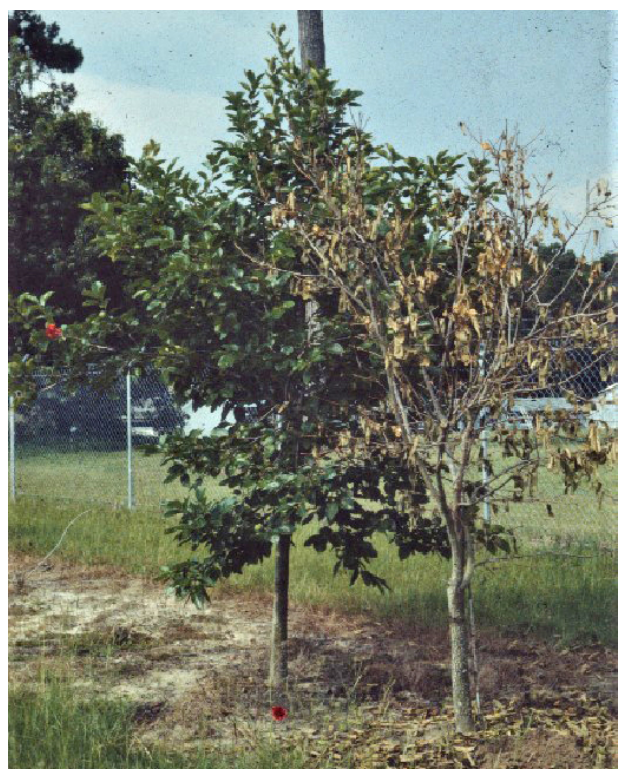

Figure 23. Whole persimmon tree decline.

Credits: UF/IFAS

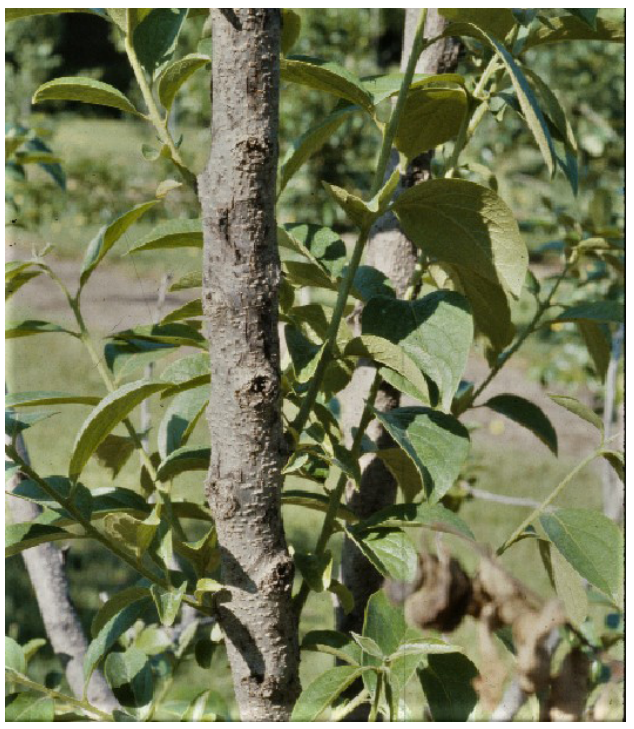

Figure 24. Persimmon decline canker on the trunk. Credits: UF/IFAS 